\title{
Trends in the methodology of media consumption study in the field of cinema in Russia
}

\section{Tendencias en la metodología del estudio del consumo de medios en el campo del cine en Rusia}

\section{Tatyana Igorevna Nikitina \\ Kazan (Volga region) Federal University,}

Ph.D. in Political Science, Associate Professor, Department of Public Relations and Applied Political Science, Graduate School of Journalism and Media Communications, Institute of Social and Philosophical Sciences and Mass Communications, 18 Kremlyovskaya str., Kazan, 420008,

Russian Federation

ORCID ID: 0000-0002-1062-9844

\section{Aleksey Aleksandrovich Nikitin \\ Kazan (Volga region) Federal University,}

$\mathrm{PhD}$ in Political Science, Associate Professor, Department of Public Relations and Applied Political Science, Graduate School of Journalism and Media Communications, Institute of Social and Philosophical Sciences and Mass Communications, 18 Kremlyovskaya str., Kazan, 420008,

Russian Federation

ORCID ID: 0000-0002-9434-3818

\section{Bulat Ildarovich Yakupov}

Kazan (Volga region) Federal University

Assistant at the Department of Public Relations and Applied Political Science of the Higher School of Journalism and Media Communications, Institute of Social and Philosophical Sciences and

Mass Communications, 18 Kremlyovskaya str., Kazan, 420008, Russian Federation ORCID ID: 0000-0003-0055-0806

Received 09-08-20 Revised 10-10-20

\section{* Correspondence}

Email: Tatjana.Nikitina@kpfu.ru

\section{Citation:}

Tatyana Igorevna Nikitina, Aleksey Aleksandrovich Nikitin, Yakupov Bulat Ildarovich. (2021). Trends in the methodology of media consumption study in the field of cinema in Russia Propósitos $y$ Representaciones, 9 (SPE2), http://dx.doi.org/10.20511/pyr2021.v9nSPE2.1090 


\begin{abstract}
The relevance of the topic is conditioned by the need for scientific understanding of media analytics and a qualitative understanding of its methods as promotion tools, as well as for the introduction of the research stage of media consumption into the film production process to popularize and further promote domestic film products among the Russian audience. In the Russian film industry, this experience is especially necessary within modern economic conditions. The need to ensure the financial success of Russian film products, which are subsidized by the state, has led to the interest in finding new approaches promoting and increasing the loyalty of the cinema audience, which is especially important at a time when only 1 out of 10 domestic films pays for their film production during the distribution period.
\end{abstract}

Keywords: media analysis, media consumption, film production, viewers, promotion.

\title{
Resumen
}

La relevancia del tema está condicionada por la necesidad de una comprensión científica de la analítica de medios y una comprensión cualitativa de sus métodos como herramientas de promoción, así como por la introducción de la etapa de investigación del consumo de medios en el proceso de producción cinematográfica para popularizar y promover aún más. productos cinematográficos nacionales entre la audiencia rusa. En la industria cinematográfica rusa, esta experiencia es especialmente necesaria en las condiciones económicas modernas. La necesidad de asegurar el éxito financiero de los productos cinematográficos rusos, que son subvencionados por el estado, ha suscitado el interés por encontrar nuevos enfoques que promuevan y aumenten la fidelidad de la audiencia cinematográfica, lo que es especialmente importante en un momento en el que solo 1 de cada 10 películas nacionales paga su producción cinematográfica durante el período de distribución.

Palabras clave: análisis de medios, consumo de medios, producción cinematográfica, espectadores, promoción.

\section{Introduction}

The study of the methods of media analytical research in its modern sense is at the stage of comprehension, however, there is a theoretical foundation that describes the general essence and problems of the topic (Lizunova, 2016; Kaminskaya, 2015; Fortuny et al., 2013). It should be noted that their practical application in specific areas of activity in Russian practice is poorly studied (Kurnosov \& Konotopov, 2004; Kurnosov, 2015; Kurnosov \& Konotopov, 2004). For a general vision of the problem, it is necessary to study existing sources that reveal the essence of media analytics, describe the main definitions, processes and key components of this phenomenon, reveal analytical research methods as tools, and also reflect the relationship between the concept and cinema marketing. The majority of these sources are books and scientific articles written by the experts in various fields: philosophical sciences, media research, and marketing (Rushkoff, 2003; Larionov, 2020; Harris et al., 2009).

\section{Methods}

The methodological basis of this work was the existing domestic and foreign works on analytics, as well as modern media consumption of both domestic and foreign practitioners. This work is based on the analysis of specialized literature, various manuals, scientific articles that consider concepts such as analytics, media consumption, promotion, not only in general terms, but also affect certain aspects and different approaches to understand terms. The study of the problem of analytics use in promotion within the field of cinema, as well as its use in the study of consumer interests, is based on the systematization of factual materials and publications in specialized publications, the profile of which is cinema. The research methods in the research process were the 
following: the methods of analysis and synthesis, system approach, the methods of classification and groupings, comparative analysis, statistical research methods, content analysis.

To carry out the research, the methods of analysis and synthesis were used, which made it possible to study theoretical sources and articles on the practical experience of research activity use in the film industry, study all approaches to basic concepts and develop a general one, analyze the activities of foreign and domestic experts; using the classification method, it was possible to describe in detail the applied research methods. The method of a systematic approach was used to combine the components into a single whole, which contribute to decision-making when developing a set of measures to promote a film product. Comparative analysis of empirical and statistical data on the topic was also widely used, the comparison method was used to determine the features of analytical activity use in the Russian film industry and foreign one, to identify trends and patterns, as well as to draw conclusions about the state of the Russian film industry. The methods of content analysis made it possible to determine quantitatively the preferences of the cinema audience in relation to the genre, as well as to assess qualitatively the audience's consumption of domestic film products, to identify the characteristics of consumption, to collect the necessary information to develop recommendations for an effective application of research methods in the popularization of domestic film products. In the course of the work, material was collected and systematized on a whole range of issues related to ongoing research.

In the course of the study, the analysis of a wide range of sources was carried out, which were the literature on the essence, purpose, stages of carrying out analytical activities, as well as the definition of its tools for research. Besides, within the framework of the study, the analysis of secondary data was carried out, which were the results of previously conducted sociological studies, statistical data from open databases and conference proceedings.

\section{Results and Discussion}

During the rapidly developing information space, one of the important and promising areas is media analytics. It makes it possible to conduct research and evaluate the effectiveness not only by quantitative indicators, but also with qualitative metrics, allowing you assess the post-effect on the audience, its reaction, perception, evaluate the retransmission of some situation by the media, and also assess the current situation for further strategy development, maintaining the achieved level or adjusting it.

The concept of "analytics" has its roots since the time of Aristotle, representing the art of analysis, and playing an important role in the methodology of science and professional activity. The discipline is universal, as it includes a large number of methods used in research, and has practical value for many professions, combining three components at once: the methodology of information-analytical work, organizational support of the process, and technological support for the development of tools. Moreover, analysis is its fundamental element.

In a broad sense, analytics is a strategic resource that permeates all spheres of life and allows you to process information material most effectively to prepare a subsequent basis to solve problems or update existing knowledge. In terminological reference books and English-economic dictionaries, as well as in the professional lexicon of advertising experts, "media analysts" are described as analyzing the process of encoding and interpreting a specific advertising message, the ways of conveying certain content, as well as considering a message through categories, values and needs, to which advertising refers, analysis and statistics of advertising and audience (Methods of Text and Discourse Analysis: Stefan Titscher, 2000).

Today, media analytic activity is understood as the process of searching, collecting, processing and presenting information in the required form. At the same time, media analytics is not just media monitoring. Monitoring itself, as a method, is included in the analytics toolkit, since only the presence of a change in some situation is determined by its results. But in order to determine the nature of this change, it is necessary to carry out the analysis and inference, drawing 
conclusions, only then the process can be called analytical. That is why most experts, speaking about analytics, focus on the intellectual activity of people, which is aimed at studying an object and its environment in order to understand a situation and transform it, as well as predict the consequences. At the same time, the classical approach to information-analytical method use includes the following algorithm: setting tasks, proposing a hypothesis, collecting the necessary material and testing this hypothesis.

It is customary to distinguish four phases in research activities (Carl Anderson, 2015; Dykes, 2010):

- the phase of conceptualization, the main task of which is to reveal trends, identify possible patterns, develop a plan-program - the definition of a subject, the identification of real-life problems, as well as the factors that caused their occurrence, the formation of initial hypotheses;

- the second phase - data collection - includes the definition of information volume, as well as the methods of empirical material collection. The main point is to ensure that reliable and representative data are obtained. The first step is to conduct a primary express analysis - to establish the essence, importance, and veracity of information (Fortuny et al., 2013). Information can be relevant if it has a connection with the solution to the problem and can make a great contribution to the process;

- the phase of processing the results obtained is the process of systematizing the collected data, their ordering using mathematical methods, qualitative analyzes, graphs and pivot tables;

- the phase of scientific substantiation of the results is associated with testing hypotheses how much the results correspond to the hypotheses put forward during the phase of conceptualization. The phase of scientific substantiation develops estimates of the main characteristics and reveals stable connections and trends.

If we represent media analytic activity in the form of a diagram, then it will look like this:

1. Media research using software systems: media database use - processing of materials using automated programs - big data analysis.

2. Media research with the help of expert analysts: a review of the necessary material - an assessment of its relevance - abstract - an assessment of quality indicators - carrying out the necessary analyzes (SWOT analysis, comparative analysis, systematic analysis, etc.) - writing conclusions and recommendations (Larionov, 2020).

The growing importance of research activity is associated with the presence of problems in practice that require study not only via automated technological methods, but also meaningful resolution (Anderson, 2012). Crisis situations, requiring analysis and obtaining information to overcome uncertainty, and an endless flow of information, which includes a contradictory flow of information that needs to be processed, played a role in the development of analytics. The modern world has a large number of objects and processes that need research and an individual choice of a study method. Modern media analysis in new media is more expanded and personified, and, of course, a huge array of personal information complicates the research process, however, the accuracy of the research results is improved. Thus, audience data in the media space has a wide range of uses. That is why there is a need for a detailed study of this huge layer of information (Davenport \& Harris, 2010; Nucleus Research, 2014).

There is a kind of synthesis of media analytics and film marketing concepts. The relevance of media analytics in the context of film production is explained by the fact that it helps to identify trends in the audience attitude to the product, for its further improvement and its marketing component increase (Lizunova, 2016; Stone, 2012). 


\section{Conclusions}

After the analysis, the following results were obtained. Media analytic activity is a complex concept, the methodology of which consists of a whole set of tools, as well as the use of a hybrid approach in research. Each person independently generates a large amount of content, so observing and studying the audience in social and new media helps not only to determine their interests and preferences, but also to identify the main problems and determine their nature.

In Russia, there is a tendency towards a serious attitude concerning the return of allocated funds for film production, which increases the responsibility of filmmakers to the state, which in turn leads to the search for new means of film production popularization. The popularization of domestic film production must be approached in a comprehensive manner. The technical support used in the Russian film industry and film mastering have made a "step forward" over the past 5-8 years and today they can compete with foreign film products, however, the content of the film products causes discussion among the cinema audience.

\section{Summary}

With the integrated use of all research methods, it is possible to increase the audience's loyalty to the film product, and accordingly the efficiency of economic activity, by developing recommendations for a film product creation that would meet all the expectations and demands of the cinema audience, based on research of its interests, needs, opinions and assessments. This is evidenced by existing foreign practice of this approach application.

\section{Acknowledgements}

The work is performed according to the Russian Government Program of Competitive Growth of Kazan Federal University.

\section{References}

(2000). Methods of Text and Discourse Analysis: Stefan Titscher, Michael Meyer, Ruth Wodak and Eva Fetter. London: Sage, vi+278 P.

Carl Anderson. (2015). Creating a Data-Driven Organization - O'Reilly Media. Inc. - 285 P. ISBN: 9781491916919

Davenport, T.H., \& Harris, J.G. (2010). Analytics at Work: Smarter Decisions, Better Results. Boston: Harvard Business Press, -240 P.

Dykes, B. (2010). Reporting vs. Analysis: What's the Difference? Digital Marketing Blog, October 19. URL: https://blogs.adobe.com/digitalmarketing/analytics/reporting-vs-analysis-whatsthe-difference/

Fortuny, E.J.de., Martens, D., \& Provost, F. (2013). Predictive Modeling with Big Data: Is Bigger Really Better? Big Data 1(4), 215-226. URL: http://online.liebertpub.com/doi/full/10.1089/big.2013.0037

Harris, J.G., Craig, E., \& Egan, H. (2009). How to Organize Your Analytical Talent (Dublin: Accenture Institute for High Performance.

Kaminskaya, T.L. (2015). Mediatization of personality: communicative aspect. World of linguistics and communication: electronic scientific journal, 4, 1-4.

Kurnosov, Yu.V. (2015). Analytics as an intellectual weapon. 2nd ed. - M.: Ritm, - 1200 p.

Kurnosov, Yu.V., \& Konotopov, P.Yu. (2004). Analytics: methodology, technology and organization of information and analytical work. - Moscow: Rusaki Publishing House,$550 \mathrm{p}$.

Kurnosov, Yu.V., \& Konotopov, P.Yu. (2004). Analytics: methodology, technology and organization of information and analytical work. - Moscow: Rusaki Publishing House, $550 \mathrm{p}$.

Larionov, E. (2020). A short guide to media analysis and evaluation of PR effectiveness. URL: http://www.akospr.ru/ (reference date: 2.02.2020). 
Lizunova, I.V. (2016). Modern media consumption: modifications of essential characteristics. Historical, philosophical, political and legal sciences, cultural studies and art history. Questions of theory and practice. - V.: Gramota, 10, 120-124.

Nucleus Research. (2014). Analytics pays back \$13.01 for every dollar spent. O204 (Boston, MA: Nucleus Research), 5. URL: http://nucleusresearch.com/research/single/analytics-paysback-13-01-for-every-dollar-spent/

Rushkoff, D. (2003). Media Virus! How pop culture secretly affects your mind. - M.: Ultra. Culture,. - p. 8.

Stone, J. (2012). Centralized vs Decentralized Analytics: All You Need to Know. April 22. URL: http://jebstone.com/2012/04/centralized-vs-decentralized-analytics-allyou-need-to-know/

Anderson, C. (2012). What is a data scientist? December 3. URL: http://www.pvalue.info/2012/12/what-is-data-scientist.html 